\title{
PENGARUH SARI KURMA TERHADAP PROLAKTIN DAN PENGELUARAN ASI PADA IBU POSTPARTUM DI BPM PIPIN HERIYANTI YOGYAKARTA TAHUN 2017
}

\author{
Dwi Yulinda ${ }^{1^{*}}$, Imroatul Azizah ${ }^{2}$
}

${ }_{1 * 2}^{*}$ Program studi Kebidanan (D-3) Stikes Jenderal Achmad Yani Yogyakarta Jln. Ringroad Barat Gamping Sleman Yogyakarta Kode Pos 552894 Indonesia e-mail liendha@yahoo.com, azizah578@gmail.com

\begin{abstract}
Background: Breastfeeding is exceptionally superior, giving mother and infants distinct and subtastial physical, mental, and developmental health advantages. Palm fruit has content of phytonutrients with antioxidant properties and galactagogues to help increase their milk supply in the early postpatum days. The lowest exclusive brest feeding rates in DIY is in the city of Yogyakarta. Exclusive breast feeding improves infant immunity so as to minimize the occurrence of diarrhea, constipation, fever that is caused by some allergic reactions.

Objectifive: :This study aimed to analyze the relationship between date palm fruits on postpartum to prolactin and volume of breast milk

Method: Research was conducted on maternal postpartum which is divided into two groups. They are the control group; and the treatment group which was given dates palm fruit. Breast milk volume and prolactin was measured at 3 day after labor. The analytical method used is Student T-test.

Results: Date Palm fruits increased prolactin and volume of breast milk which was significantly on firstweek breastfeeding increase in the treatment group compared to the control group at $p<0.05$.

Conclusion: Date Palm fruits is one of the alternatives that can be done to improve the success of exclusive breast feeding on postpartum.
\end{abstract}

Key Words: Date palm fruit, postpartum, prolactin and volume of breast milk

\section{PENDAHULUAN}

Pemberian ASI segera setelah bayi lahir memberikan manfaat bagi ibu yaitu sebagai KB alami, mempercepat kembalinya uterus dan mengurangi terjadinya kanker payudara. Sedangkan manfaat bagi bayi yaitu sebagai sistem imun, mencegah penyakit, meningkatkan berat badan, dan meningkatkan kecerdasan. ASI juga mengandung zat kekebalan yang melindungi bayi dari berbagai penyakit infeksi serta zat antibodi. Zat antibodi di dalam ASI paling banyak terdapat di dalam kolostrum yang mengandung immunoglobulin terutama $\lg \mathrm{A}{ }^{1}$

Upaya untuk mengurangi pendarahan dan untuk meningkatkan produksi ASI dapat dilakukan dengan memberikan rangsangan berupa pemijatan, atau pemberian suplementasi untuk meningkatkan produksi ASI. Beberapa tahun belakangan ditemukan berbagai macam tumbuhan yang mengandung galaktogogus dapat membantu pengeluaran dan produksi ASI antara lain daun katuk, fenugreek, dan kurma. Galaktogogus dapat menginduksi laktasi dengan menekan antagonis reseptor dopamin sehingga terjadi peningkatan produksi prolaktin. $^{2}$ Data Kementerian Kesehatan pada Pekan ASI tahun 2013 cakupan ASI Eksklusif di Indonesia jauh dari target tahun 2012 80\% dan mengalami penurunan dari 61,5\% tahun 2011 menjadi $61,1 \%$ tahun $2012 .^{3}$ 
Tahun 2012 cakupan ASI Eksklusif di Daerah Istimewa Yogyakarta terendah berada di Kota Yogyakarta 1.323 bayi. Pemberian ASI eksklusif selama 6 bulan sangat dipengaruhi oleh keberhasilan menyusui dini. Pemberian ASI secara dini akan menstimulasi produksi ASI dengan meningkatkan prolaktin. Upaya untuk mengurangi pendarahan dan untuk meningkatkan produksi ASI dapat dilakukan dengan memberikan rangsangan berupa pemijatan, atau pemberian suplementasi untuk meningkatkan produksi ASI. ${ }^{4}$

Kurma (Phoenix dactylifera) merupakan tanaman yang banyak digunakan oleh masyarakat Indonesia. Buah kurma mengandung zat besi, protein, serat, glukosa, vitamin, biotin, niasin, asam folat, dan mineral seperti kalsium, sodium, dan kalium. Kadar protein pada buah kurma sekitar 1,8-2 \%, kadar glukosa sekitar 50- $57 \%$, dan kadar serat $2-4 \%$. Mineral dalam buah kurma yang salah satunya adalah potasium yang dapat menghalangi reseptor dopamin, dan kemudian merangsang pelepasan prolaktin. Kurma juga memiliki kandungan protein yang dapat meningkatkan produksi ASI dengan meningkatkan metabolisme glukosa untuk sintesis laktosa. ${ }^{5,6}$

\section{BAHAN DAN CARA PENELITIAN}

Penelitian ini dilakukan secara eksperimental dengan Rancangan Acak Lengkap (RAL) menggunakan post test dengan kelompok kontrol (Post Test Only
Control Group Design). Penelitian ini dilakukan pada ibu postpartum. Tempat penelitian ini di BPM Pipin Heriyanti, Yogyakarta pada bulan Mei-September 2017. Penelitian ini telah mendapatkkan persetujuan dari Komite Etik Stikes Jenderal Achmad Yani Yogyakarta.

Pada penelitian ini responden dibagi menjadi 2, yaitu kelompok kontrol dan kelompok perlakuan yaitu ibu postpartum yang diberikan sari kurma. Selanjutnya pada hari ketiga dilakukan pengukuran kadar prolaktin dengan metode ECLIA (electrochemiluminescence Immunoassay) dan pengeluaran ASI dengan menggunakan pompa ASI.

\section{HASIL DAN PEMBAHASAN}

Pengujian data menggunakan Anova $(p<0,05)$ yang sebelumnya dilakukan Uji normalitas menggunakan Shapiro Wilk dan uji homogenitas menggunakan Levene test. Dan dilanjutkan pengujian LSD.

Analisis data dengan menggunakan penghitungan uji statistik. Saphiro-Wilk untuk mengetahui normalitas data $(p>0,05)$, Levene digunakan untuk menentukan homogenitas data $(p>0,05)$. Jika asumsi normalitas tidak terpenuhi maka dilakukan dengan menggunakan uji Mann Whitney. Student $t$ test digunakan untuk mengetahui apakah ada perbedaan antara kelompok perlakuan dengan kelompok kontrol terhadap peningkatan jumlah pengeluaran ASI. Uji Kai Kuadrat untuk mengetahui apakah ada 
perbedaan pada 2 kelompok perlakuan dan kontrol.

Tabel 1. Perbandingan Kadar Prolaktin Kelompok Kontrol Dengan Perlakuan Sari Kurma

\begin{tabular}{lccc}
\hline Kelompok & $\begin{array}{c}\text { Rata-Rata } \\
\text { Kadar } \\
\text { Prolaktin } \\
\text { (n) }\end{array}$ & $\begin{array}{c}\text { Z- } \\
\text { hitung }\end{array}$ & $\begin{array}{c}\text { p- } \\
\text { value }\end{array}$ \\
\hline Kontrol & 272,93 & $-2,358$ & 0,018 \\
Perlakuan & 398,18 & & \\
\hline
\end{tabular}

Sumber: Data Primer, 2017

Berdasarkan tabel 1, hasil

pengeluaran rata-rata prolaktin pada kelompok perlakuan lebih banyak daripada kelompok kontrol. Salah satu komponen dalam kurma yaitu antioksidan, potasium, dan tingginya protein yang berfungsi meningkatkan fosforilasi cAMP-dependent dengan mengaktifkan sinyal CAMP/PKA yang akhirnya menghambat reseptor D2 dopamin. Phosphodiesterases (PDEs), yaitu enzim yang mendegradasi cAMP dan menekan perangsangan sinyal CAMP/PKA, mengontrol sinyal dopaminergik. PDE10A terutama mengatur fosforilasi DARPP- 32i, sehingga menghambat PP-1 dan memengaruhi sinyal dopaminergik. Dengan mekanisme ini, potasium/kalium menghalangi reseptor dopamin, dan kemudian merangsang pelepasan prolaktin. Dengan adanya prolaktin yang tinggi maka produksi asi akan meningkat. Prolaktin banyak terdapat pada ibu yang sedang menyusui, karena ia adalah hormon penting yang merangsang kelenjar susu untuk memproduksi susu, sehingga pada saat diperlukan siap berfungsi. ${ }^{7}$ Adanya aktivitas menyusui dari bayi ini maka hormon prolaktin akan ikut bekerja dengan sempurna, selain itu dengan tingginya hormon prolaktin pada masa menyusui, hormon ini juga bekerja menghambat terjadinya siklus menstruasi selama menyusui, sehingga ibuibu yang secara aktif menyusui bayinya akan mendapat kembali menstruasi agak lama, sekitar 6 bulan sampai 1 tahun.,

Peran prolaktin pada proses menyusui tidak akan sempurna tanpa adanya bantuan oksitosin yang membantu pengeluaran ASI. Proses penyampaian ASI dari ibu ke bayi dan pemeliharaan proses laktasi tergantung pada mekanisme pada puting susu. Hisapan bayi merupakan stimulasi utama dalam pengeluaran ASI, walaupun reflek pengeluaran ASI dapat dikondisikan., 8

Salah satu teori persalinan adalah adanya hormon estrogen dan progesteron turun secara drastis sehingga digantikan oleh hormon prolaktin dan okstosin. Hormon prolaktin dan oksitosin memainkan peran dalam proses laktasi sehingga pengeluaran ASI akan lancar. Tidak keluarnya ASI bukan karena produksi ASI yang tidak ada atau tidak mencukupi, tetapi sering kali produksi ASI cukup namun pengeluarannya terhambat akibat hambatan sekresi oksitosin. ${ }^{10}$

\begin{tabular}{lccc}
\multicolumn{3}{c}{$\begin{array}{c}\text { Tabel 2. Perbandingan Volume ASI Kelompok } \\
\text { Kontrol dengan Perlakuan Sari kurma }\end{array}$} \\
\hline Kelompok & $\begin{array}{c}\text { Rata-Rata } \\
\text { Volume ASI (ml) }\end{array}$ & $\begin{array}{c}\text { t- } \\
\text { hitung }\end{array}$ & $\begin{array}{c}\text { p- } \\
\text { value }\end{array}$ \\
\hline Kontrol & 228 & $-2,283$ & 0,005 \\
Perlakuan & 283,3 & & \\
\hline
\end{tabular}

Sumber: Data Primer, 2017 
Hasil penelitian ini menunjukkan pengeluaran rata-rata ASI pada kelompok perlakuan lebih banyak daripada kelompok kontrol. Hal ini sesuai dengan teori yang mengatakan bahwa dalam sari kurma mengandung Galaktogogus yang merupakan agen farmasetikal, makanan, atau suplementasi herbal yang berfungsi untuk membantu memperlancar pengeluaran ASI. ${ }^{11}$ Pengeluaran ASI di pengaruhi oleh hormon oksitosin. Oksitosin dapat diperoleh dengan berbagai cara baik melalui oral berupa terapi, atau makanan (kurma, fenugreek), intranasal, intra-muscular, maupun dengan pemijatan yang merangsang keluarnya hormon oksitosin. Isapan bayi menstimulasi ujung saraf sensorik pada puting susu dan areola payudara, dan impuls tersebut berjalan sepanjang serat aferen menuju korda spinalis yang selanjutnya akan bergerak ke traktus spinotalamikus lateral, dorsal, dan ventral menuju otak tengah. Serat eksitatorik diproyeksikan secara langsung ke neuron oksitosin pada hipotalamus, mengakibatkan pelepasan oksitosin oleh hipofisis. Dengan adanya oksitosin yang dikeluarkan hipofisis maka pengeluaran ASI dapat terjadi. ${ }^{12}$

Faktor-faktor yang memengaruhi volume pengeluaran ASI antara lain frekuensi menyusui, berat badan bayi, usia kehamilan saat persalinan, paritas, stres, dan penggunaan kontrasepsi. Pada penelitian ini bebe- rapa faktor tersebut pada hari ke-3 sebelum pengukuran ASI diabaikan, sehingga menjadi kelemahan dalam penelitian ini.

\section{KEPUSTAKAAN}

1. Maryunani, Anik. Ilmu Kesehatan Anak Dalam Kebidanan. Jakarta: TIM. 2012.

2. Gabay,MP. Galactogogues: Medications That Induce Lactation. J Hum Lact 18(3), 2002: 274-279. 2002.

3. Kemenkes, RI. 2013. Profil Kesehatan Yogyakarta Tahun 2013. Yogyakarta.

4. Dinas Kesehatan Provinsi DIY. Profil Kesehatan DIY tahun 2014. Yogyakarta: Dinkes DIY;2013

5. M.S Beliga et al. A Review of The Chemistry and Pharmacology Of The Date Fruits ( Phoenix dactylifera L.). Elsevier 44 (1812-1822) 2011.

6. Jahromi K, Rafiee, Jafari A, Tabatabaeefar. 2007. Determination of dimension and area properties of date (Barhi) by image analysis. Agric Food and Biol Eng 15: 21-24

7. Bobak IM, Lowdermilk DL, Jensen MD.. Buku Ajar Keperawatan Maternitas (Maternity Nursing) Edisi 4, Maria A Wijayarti dan Peter Anugerah (penterjemah). 2005. Jakarta: EGC.

8. Heffner LJ. At A Glace Sistem Reproduksi. Edisi Kedua. Jakarta: EMS. 2010

9. Fraser, DM \& Cooper, MA. At A Glace Sistem Endokrin. Jakarta: EMS. 2009.

10. Varney, Helen., Kriebs, Jan M., Gegor C.L. Buku Ajar Asuhan Kebidanan. Edisi 4 Volume 2. Jakarta : EGC. 2008

11. Sakka AE, Salama M, Salama K. The Effect of Fenugreek Herbal Tea and Palm Dates on Breast Milk Production and Infant Weight. Journal of Pediatric Sciences.;6:e202. 2014.

12. Greenstein, B \& Wood, D. At A Glace Sistem Endokrin. Edisi Kedua. Jakarta: EMS. 2010. 